Man and Nature

L'homme et la nature

\title{
From Terror to the Terror: Changing Concepts of the Gothic in Eighteenth-Century England
}

\section{Peter Sabor}

Volume 10, 1991

URI : https://id.erudit.org/iderudit/1012633ar

DOI : https://doi.org/10.7202/1012633ar

Aller au sommaire du numéro

Éditeur(s)

Canadian Society for Eighteenth-Century Studies / Société canadienne d'étude du dix-huitième siècle

ISSN

0824-3298 (imprimé)

1927-8810 (numérique)

Découvrir la revue

Citer cet article

Sabor, P. (1991). From Terror to the Terror: Changing Concepts of the Gothic in Eighteenth-Century England. Man and Nature / L'homme et la nature, 10, 165-178. https://doi.org/10.7202/1012633ar

Copyright (c) Canadian Society for Eighteenth-Century Studies / Sociéte canadienne d'étude du dix-huitième siècle, 1991
Ce document est protégé par la loi sur le droit d'auteur. L'utilisation des services d'Érudit (y compris la reproduction) est assujettie à sa politique d'utilisation que vous pouvez consulter en ligne.

https://apropos.erudit.org/fr/usagers/politique-dutilisation/ 


\section{From Terror to the Terror: Changing Concepts of the Gothic in Eighteenth-Century England}

In the cloistered, nightmarish, supernatural world of literary Gothicism, clocks and chronology are in abeyance. Bells may chime out the hour from some lonely ruined turret, but they are unlikely to convey any clear sense of time. The action may be set in some vaguely medieval period, but without a particular decade or even century being specified. Entrapped in dank dungeons, Gothic protagonists are sequestered from the diurnal current of events. As if affected by this characteristic timelessness, modern critics have been largely indifferent to questions of change and development in eighteenth-century attitudes to the Gothic, and too ready to identify an unbroken chain of Gothicists stretching from the turn of the seventeenth century to the end of the Romantic period. The progenitor of this approach was the most devoted of all Gothic scholars, Montague Summers, whose The Gothic Quest (1938) begins with a catch-all chapter entitled 'The Romantic Feeling,' in which eighteenth-century authors of all kinds and dates make fleeting appearances. Pope's 'Eloisa to Abelard,' for example, is said to 'show such Gothic influences as might almost be paralleled in Mrs. Radcliffe herself,' while certain lines 'have not a little of the pale spirit of Monk Lewis. ${ }^{1}$ In the same tradition, Devendra Varma's The Gothic Flame (1957) contains a chapter exploring the roots of Gothicism in Spenser, Shakespeare, and Milton, as well as in eighteenth-century graveyard poetry. ${ }^{2}$ Dan McNutt's useful secondary bibliography of the Gothic novel (1975) has a chapter on the 'Literary Background,' surveying a range of quasiGothic passages from authors such as Dennis, Addison, and Defoe. ${ }^{3}$ More recently, Frederick Frank's The First Gothics (1987) insists again that Pope's 'night thoughts' in Eloisa to Abelard 'anticipate ... the core of the Gothic experience,' and that in his Philosophical Enquiry into the Origin of Our Ideas of the Sublime and Beautiful (1757) Burke expounded 'the psychological foundations of the Gothic' even before the Gothic novel or drama had been created. ${ }^{4}$ Elsewhere Frank writes of Thomas Warton's 'The Pleasures of Melancholy' (1745), in which the poet, 'standing in 
ecstatic anxiety upon the threshold of the Gothic world ... sounds precisely like a Gothic victim. ${ }^{5}$

In contrast to these and other critics who find a meaningful continuity between Dryden and Drake or the Wartons and Walpole, my purpose here is to emphasize the way' in which attitudes towards Gothicism changed over the course of the eighteenth century. To do so, I have focused on theories of terror: on the writers who considered the aesthetics of terror in the early century, on the first uses of this term in the context of Gothicism in the 1760s, and on its new connotations in the 1790s, when terror was made incarnate by the Reign of Terror in France.

It has often been noted that as a literary-critical term, the word 'Gothic' had almost entirely negative connotations throughout the first half of the eighteenth century. ${ }^{6}$ Alfred Longeuil observes that the word is synonymous with 'barbarous' during this period, and the two words are frequently coupled together; examples of this pairing can be found in Dennis, Addison, and many other authors. ${ }^{7}$ Undeterred by this fact, however, modern critics have been eager to demonstrate the prevalence of 'pre-Gothicism' in the early eighteenth century, and both Dennis and Addison, despite their pejorative use of the term, have been enlisted in this cause.

It is true that some passionate defences of the use of terror and horror in literature were made by early eighteenth-century authors. In a letter written as early as 1688, Dennis terms the Alps 'not only vast, but horrid, hideous, ghastly Ruins,' and does so not in disgust but in tremulous enthusiasm. The spectacle of vast rocks and foaming waterfalls, writes Dennis, 'made all such a Consort up for the Eye, as that sort of Musick does for the Ear, in which Horrour can be joyn'd with Harmony. ${ }^{8}$ In his later critical essays, Dennis strives to explain the paradoxical pleasure that such horrifying sights can afford. It is, however, notable that in these works, such as 'The Advancement and Reformation of Modern Poetry' (1701) and 'The Grounds of Criticism in Poetry' (1704), Dennis relies heavily on the authority of Aristotle and Longinus, who were themselves preoccupied with the role of terror and horror in literature. Similarly, when Addison, in 1712, writes of supernatural phenomena that 'raise a pleasing kind of Horrour in the Mind of the Reader' and 'favour those secret Terrours and Apprehensions to which the Mind of Man is naturally subject, ${ }^{\prime 9}$ he is paraphrasing Longinus's account of horror as a source of the sublime in his famous essay, Peri Hypsous.

Rather, then, than regarding the early eighteenth-century writers on terror and horror as Gothicists before their time, it is, I believe, more fruitful to consider them in the context of their classical precursors. It is significant, in this regard, that one of the fullest accounts of the aesthetics of terror in the early eighteenth century occurs in William Smith's notes 
to his translation of Longinus (1739), which became the standard English version of its time. ${ }^{10}$

While 'Gothic' remained a term of abuse in early eighteenth-century critical vocabulary, there was a growing interest in the sublime. Important modern studies such as those by Samuel Holt Monk and Walter Hipple have shown how writers on the sublime explored the complex relationship between terror, horror, and aesthetic pleasure and fulfillment. ${ }^{11}$ Treatises such as John Baillie's Essay on the Sublime (1747), Alexander Gerard's An Essay on Taste (1759), and, by far the most impressive and influential, Burke's Philosophical Enquiry (1757), are centrally concerned with this issue - yet all of these works either ignore the Gothic entirely or else equate it with primitive barbarism. Samuel Johnson, similarly, while commending Burke's essay as an 'example of true criticism' and urging critics of drama to 'shew how terrour is impressed on the human heart,' had little to say on the Gothic; the word does not occur as a critical term in his Dictionary, and in 1784 he spoke dismissively of the writings of Horace Walpole, founder of both the Gothic novel and drama, as 'a great many curious little things. ${ }^{12}$

In light of this widespread critical disdain, Richard Hurd's vigorous espousal of Gothicism in his Letters on Chivalry and Romance (1762) is of seminal importance. From the outset, Hurd challenges the prevailing equation of the Gothic with barbarism, demanding 'what ... is more remarkable than the Gothic CHIVALRY?'13 Contrasting Gothic with classical literature, Hurd considers passages from Chaucer, Spenser, Shakespeare and Milton as examples of literary Gothicism. Although the reception of this innovative work was surprisingly positive, in a second edition of the Letters published three years later Hurd deleted some of his most interesting claims. In 1762, but not in 1765, he declares that 'the mummeries of the pagan priests were childish, but the Gothic Enchanters shook and alarmed all nature,' and 'the horrors of the Gothic' (1762), which are 'above measure striking and terrible,' becomes merely 'the Gothic' in $1765 .{ }^{14}$ An ambitious clergyman, later to become a bishop, Hurd might have been alarmed by the depiction of his work in the Monthly Review. Although the review was long and highly favourable, the terms of praise were disconcerting: 'The ORTHODOX in Poetry will, no doubt, look upon him as a daring HERETIC, and, as such, thunder out their excommunications against him. ${ }^{15}$ Despite his retrenchments, however, Hurd was the first English critic to consider the depiction of horror and terror in literature as a mode in itself, and to term this mode the Gothic. It is regrettable that his modern editor, Hoyt Trowbridge, has sought to diminish his originality, insisting that Hurd is not 'attacking the critical principles or general theory of poetry which were accepted in his time. ${ }^{16}$ Letters on Chivalry and Romance goes far beyond any 
previous work in its analysis of the Gothic, singling out for study a tradition of English writing that had not previously been identified.

Some of Hurd's contemporaries, without using the term 'Gothic,' took a particular interest in the aesthetics of terror. Published in the same year as Letters on Chivalry, Henry Home, Lord Kames's Elements of Criticism makes an interesting attempt to distinguish between 'horror' and 'terror' - a subject to which several subsequent critics would return. 'Objects that strike terror in a spectator,' declares Kames, 'have in poetry and painting a fine effect,' but not so objects of horror, which arouse only disgust: 'Every thing horrible ought therefore to be avoided in a description. ${ }^{17}$ Unbeknown to Kames, Samuel Richardson had in 1748 made a similar distinction between horror and terror in a letter to Lady Bradshaigh: Those Acts, Madam, may be called Acts of Horror by tender Spirits, which only ought to be called Acts of Terror and Warning'; he himself has avoided all horror, while admitting the necessity for 'Terror and Fear and Pity.' ${ }^{\prime 8}$

The efforts made by Richardson and Kames to distinguish horror from terror contrast with Burke's mingling of the two terms in his Philosophical Enquiry, in which he characterises the sublime as 'a sort of delightful horror, a sort of tranquillity tinged with terror. ${ }^{19}$ Both terms occur repeatedly in the Enquiry, and each is said, at different times, to be both the source and test of the sublime. Burke's refusal to distinguish horror from terror was vexing to subsequent theorists of the Gothic, who continued, with little success, to attempt to establish distinctions between the two terms.

While the publication of Hurd's and Kames's treatises paved the way for Walpole's publication of The Castle of Otranto two years later in 1764, Walpole distanced himself from both authors. Of Hurd he declared in a letter of 1781 that 'all his writings are tame, without a grain of originality,' and while he thanked Kames formally for a presentation copy of Elements of Criticism in 1762, there is no evidence of his having read it. ${ }^{20}$ Walpole's passion for the Gothic was architectural, rather than literary, and he made no attempt to justify his Gothic writings by referring to the new theorists of the Gothic mode. He was far readier to publicize his Gothicizing of Strawberry Hill than his Gothic literary productions. Only fifty copies of his Gothic drama, The Mysterious Mother (1768), were printed at his private press, and copies were withheld from the review journals. The Castle of Otranto was first published under the guise of a translation 'from the Original Italian of Onuphrio Muralto,' and Walpole's authorship remained unknown except to a few close friends. Only after thus testing the waters did Walpole reveal his authorship, signing the preface to the second edition of 1765 with his intitials and terming 
the novel 'a Gothic story' on the titlepage: the first time that an eighteenth-century novel had been so labelled by its author.

The initial reception of The Castle of Otranto was mixed. Thomas Gray, an unusually timorous reader, told Walpole that it 'makes some of us cry a little, and all in general afraid to go to bed o'nights, ${ }^{21}$ but other early readers responded with contempt, rather than terror. For Gilly Williams, a friend of Walpole, it was 'such a novel, that no boardingschool Miss of thirteen could get half through without yawning'; for an anonymous reviewer in the Critical Review 'the publication of any work, at this time, in England composed of such rotten materials, is a phenomenon we cannot account for'; while John Langhorne in the Monthly Review marvelled that Walpole 'should be an advocate for re-establishing the barbarous superstitions of Gothic devilism.. ${ }^{22}$ Walpole's response to such criticism was to disclaim serious pretensions for his novel. In his correspondence, he repeatedly refers to The Castle of Otranto as a work dashed off in jest, and complains of the solemnity of those who take his nonsense seriously.

In his preface to the first edition of Otranto, Walpole had described the work in very different terms. In justifying his use of terror, 'the author's principal engine,' he declares that it 'prevents the story from ever languishing; and it is so often contrasted by pity, that the mind is kept up in a constant vicissitude of interesting passions. ${ }^{23}$ Here, for the first time, an Aristotelian theory of terror had been applied directly to an eighteenth-century Gothic novel, but by an anonymous author disguised as translator, commenting on a purportedly medieval Italian original. In propria persona, Walpole made no such claims for his novel.

Six years later, in a footnote added to his edition of Pope (1770), William Warburton made the connection between Gothic terror and Aristotelian catharsis more explicit. Observing that Otranto is set 'in Gothic chivalry,' Warburton contends that it effects 'the full purpose of the ancient Tragedy, that is, to purge the passions by pity and terror.'24 Although Walpole himself derided Warburton's account as 'an intention I am sure I do not pretend to have conceived, ${ }^{25}$ the passage is of considerable importance. The editor of Pope, invoking the authority of Aristotle, had bestowed classical dignity on a new and still highly suspect literary genre, in the same way that critics such as Dennis and Addison had earlier invoked Longinus to support the growing interest in the sublime.

In 1777, Clara Reeve published her novel The Champion of Virtue, subtitled, like the second edition of The Castle of Otranto, 'A Gothic Story.' It too was published anonymously, in the guise of a translation from an old English manuscript, and like Walpole, Reeve revealed her identity in the second edition, published a year later as The Old English Baron. 
Reeve's preface to the second edition is of considerable interest, challenging Walpole's mode of Gothicism in Otranto. While describing her novel as 'the literary offspring of the Castle of Otranto,' Reeve criticizes Walpole's work for its excessive use of the supernatural, and consequent disregard for verisimilitude: 'Had the story been kept within the utmost verge of probability, the effect had been preserved, without losing the least circumstance that excites or detains the attention. ${ }^{26}$

Walpole, in turn, disliked The Old English Baron, 'professedly written in imitation of Otranto, but reduced to reason and probability! It is so probable, that any trial for murder at the Old Bailey would make a more interesting story. ${ }^{, 27}$ Nonetheless, the convention of ultimately attributing apparently supernatural phenomena to natural causes became a staple device of subsequent novelists, including Charlotte Smith, Ann Radcliffe, William Godwin, and, of course, Jane Austen in Northanger Abbey. Reviewers of The Mysteries of Udolpho, as Cooke has noted, admired this aspect of the novel, akin to that of the modern detective story, in which 'mysterious terrors are continually exciting in the mind the idea of a supernatural appearance, keeping us, as it were, upon the very edge and confines of the world of spirits, and yet are ingeniously explained by familiar causes. ${ }^{28}$ The device was of particular use to politically involved novelists such as Godwin, who used it to link the Gothic and the everyday world. The lack of 'familiar causes' explaining the supernaturalism of Otranto made the work attractive to readers such as Walpole himself, who regarded Gothic fiction less as a political device than as playful fantasy. But another kind of Gothic novel descended from The Old English Baron, a work that feminist critics could justly reclaim as mother of the Gothic novel. ${ }^{29}$

In criticism of the Gothic before the 1790s, there are few references to contemporary politics. Although Samuel Kliger and more recent critics have associated the vogue for medievalism and the Gothic in later eighteenth-century England with Whig politics and ideals of personal liberty, Whig enthusiasts for the Gothic such as Walpole rarely linked politics with aesthetic taste. ${ }^{30}$ Kliger quotes a Tory spokesman, William Whitehead, writing against the Gothic in 1753, but similarly hostile pronouncements on the Gothic in the 1750s were made in the Monthly Review by Whig supporters such as Ralph Griffiths and William Kenrick. ${ }^{31}$ Before the 1790s, the respective place of horror and terror, the proper use of the supernatural, and the necessity for imparting moral instruction, as well as mere entertainment, were the principal critical concerns.

The outbreak of the French Revolution, however, utterly changed the terms of the discussion, so that in the 1790 s criticism of the Gothic became inextricably linked with commentary on the current events in 
France. Historians of the Revolution have long been concerned with the ways in which Romantic ideas of liberty and equality were used to justify violence and terror in France. There has, however, been much less discussion of the ways in which this violence affected the reception of the Gothic in England during the revolutionary decade. In his important study Representations of Revolution (1789-1820), Ronald Paulson approaches this issue indirectly. He contends, rightly I believe, that the popularity of Gothic fiction in the 1790s 'was due in part to the widespread anxieties and fears in Europe aroused by the turmoil in France finding a kind of sublimation or catharsis in tales of darkness, confusion, blood, and horror. ${ }^{32}$ Paulson also draws attention to the use that Burke made of his own early ideas in the Philosophical Enquiry to characterise the particular horrors and terrors of the Revolution, repeatedly displayed in Burke's later writings as appalling examples of the false sublime. ${ }^{33}$ Paulson, is not, however, concerned with the explicit connections made between Gothic horror and terror and the horror and terror of the Revolution, the subject of the third part of my essay.

On 25 July 1789, less than two weeks after the fall of the Bastille, Walpole wrote to Elizabeth Carter, 'I do not conceive that the whole frame and machine of a vast country can be overturned and resettled by a coup de baguette, though all the heads in it have been changed as much as when millions of Goths invaded nations and exterminated the inhabitants. ${ }^{34}$ For a man who for some forty years had prided himself on his own Gothic taste, this is an extraordinary remark. Walpole has reverted to the old equation of Gothic with barbarism, and sees only such barbarism in the fall of the Bastille and its aftermath. In the hundreds of extant letters by Walpole written between 1789 and his death in 1797, there are scarcely any references to literary Gothicism. In a letter to Lady Ossory of 1792, he refers to Charlotte Smith's recently published Desmond as 'Mrs Somebody's novel ... I have never seen it, nor ever will. ${ }^{35}$ In another letter to Lady Ossory of 1794, he admits to having read 'some of the descriptive verbose tales, of which your Ladyship says I was the patriarch by several mothers,' but he has no sympathy with their technique of 'excluding the aid of anything marvellous.' ${ }^{36}$ There are no references at all to Ann Radcliffe, William Godwin, or Matthew Lewis; the only Gothic novel in Walpole's library remained The Old English Baron by his old rival, Clara Reeve.

Unlike Walpole, Reeve continued to produce Gothic fiction, but she too took a stand against the Revolution. In the preface to her final novel, Memoirs of Sir Roger de Clarendon (1793), she declares her intent of using the work as an anti-Revolutionary document, giving 'a faithful picture of a well governed kingdom, wherein a true subordination of ranks and degrees was observed, and of a great prince at the head of it. ${ }^{37}$ Britain, 
she asserts, should 'shudder at the scene before her, and grasp her blessings the closer' (I, xx); 'shudder,' a verb closely associated with readers' responses to the Gothic, is here transferred to responses to the Terror in France. In a similar play on words at the end of the novel, Reeve declares that 'the late events have not only ruined France, but all Europe is injured by them' (III, 225). Gothic ruins have turned into the desecrated monuments of the ancien régime.

Richard Payne Knight's long didactic poem, The Landscape, was published a year after Reeve's novel at the height of the Terror, in 1794. In the third and final book, Knight contrasts the beauties of the English landscape with the dismal horrors of southern Europe and Africa, whose unhappy inhabitants are ravaged by 'fell scorpions,' 'prowling tiger,' 'scaly serpent,' 'the wolf,' 'the hungry lion,' 'fen-suck'd vapours,' 'poisonous reptiles,' 'buzzing insects,' 'pestilential flies,' 'dark gulfs of subterraneous fire,' 'blazing floods,' 'earthquakes' and 'yawning chasms. ${ }^{38}$ Thus far, Knight presents a typically Gothic catalogue, and in subsequent verses he seems to be continuing in a similar vein:

Who weeps not o'er the damp and dreary cell,

Where fallen majesty is doom'd to dwell;

Where waning beauty, in the dungeon's gloom,

Feels, yet alive, the horrors of the tomb!

... She counts the moments, till the rabble's hate

Shall drag their victim to her welcome fate! (III, 405-14)

His victim, however, is no fictional heroine but Marie-Antoinette herself; and in a footnote of some 1500 words Knight provides an account of the events that led to her death. Through this fusion of Gothic poetry and historical analysis, Knight implies that literary Gothicism can no longer be written without invoking current events; the 'horror' he is exploring is not merely a critical term.

Knight continued his study of the links between theories of terror and real-life horrors in his Analytical Inquiry into the Principles of Taste (1805), which went through three editions in that year, and an extensively revised fourth edition in 1808. His principal adversary here is Burke, whom he accuses of naively propounding theories of terror without regard for the consequences of his ideas. At the height of his onslaught, Knight blames Burke both for fathering Gothic productions, 'which teem with all sorts of terrific and horrific monsters and hobgoblins, ${ }^{39}$ and for being blind to the use that tyrannical oppressors would make of his justifications of terror. In his long poem of 1796, The Progress of Civil Society, Knight had also emphasized the links between Gothic writing 
and contemporary politics. In Book six, 'Of Government and Conquest,' he writes of

Scenes which, infix'd in memory, remain,

And fancy's images with horror stain;

Each mild impression from the heart erase,

And, with terrific gloom, the soul debase. ${ }^{40}$

Once again, both 'horror' and the 'terrific' feature prominently in a political context, and 'gloom,' one of Walpole's favourite Gothic terms, is here transferred to the aftermath of the Terror.

A similar transference takes place in an essay by Germaine de Staël, an émigrée in London from 1793 to 1795 . Her political writings, Réflexions sur le procès de la reine (1793) and Réflexions sur la paix (1794) were followed by her Essai sur les fictions (1795), ostensibly devoted to literary concerns. Like other writers of the 1790s, however, de Staël could not exclude political commentary from her critical remarks. Like Clara Reeve, she had little patience with the use of the supernatural in literature: 'La fiction merveilleuse cause un plaisir très-promptement épuisé. ${ }^{41}$ But the reasons she gives for her strictures are new. In the face of the Terror, 'les crimes sanguinaires dont nous venons d'être les témoins' (II, 182), supernatural terrors have come to seem merely jejune.

One result of such strictures was that Gothicists intensified the degree of horror and terror in their works to a new extreme, as Lewis did in his notorious novel, The Monk (1796). The consequence, however, was that rather than being accused of triviality and irrelevance, Lewis and other writers of high Gothic were said to have been corrupted by the excesses of the Terror. Such a charge was made by Thomas Mathias in his long splenetic poem, The Pursuits of Literature (1794-97), in which a trickle of verse is supported by a vast apparatus of notes and prefatory matter. In the preface to the third dialogue of his poem (1796), Mathias declares that 'literature, well or ill conducted, is the great engine by which ... all civilized states must ultimately be supported or overthrown. ${ }^{42}$ And in the preface to the fourth dialogue (1797), turning his attention to Lewis, Mathias identifies The Monk as just the kind of work by which the body politic was endangered. Demanding the suppression of the novel, Mathias enquires dramatically, 'Is this a time to poison the waters of our land in their springs and fountains? Are we to add incitement to incitement, and corruption to corruption?' (p. 242).

Another, wittier opponent of the high Gothic was the pseudonymous writer of an essay in the Monthly Magazine for 1797 on the Terrorist System of Novel-Writing.' We have, declares the author ironically, 
'exactly and faithfully copied the SYSTEM OF TERROR, if not in our streets, and in our fields, at least in our circulating libraries, and in our closets. ${ }^{43}$ The author attributes the popularity of the Gothic novel at the end of the century to Robespierre, who, 'with his system of terror ... taught our novelists that fear is the only passion they ought to cultivate ... our genius has become hysterical, and our taste epileptic' (p. 103). The essay goes on to parody the typical adventures of a terrified Gothic heroine, trapped in a lonely ruined castle, in which she will encounter all that is 'horrible and terrible' (p. 104). Behind the wit is a serious charge; in using the signature 'A Jacobin Novelist,' the author implies that the novel of terror has been an apologia for the Terror and its attendant horrors.

It was, of course, possible to theorize on Gothic terror in the late 1790s without alluding to the events in France, but such writing was atypical. I wish to conclude by considering two authors seldom linked together, whose remarks on the Gothic are characteristic of the Revolutionary decade: the Marquis de Sade and Jane Austen. Like de Staël, de Sade was an admirer of the English novel, in particular the works of Richardson and Fielding, 'qui nous ont appris que l'étude profonde du coeur de l'homme, véritable dédale de la nature, peut seul inspirer le romancier. ${ }^{44}$ And like de Staël, de Sade draws a comparison between Gothic and Revolutionary terror. De Sade's analysis of this connection, however, goes further. The Gothicist, he states, could scarcely depict events more appalling than those taking place in France: 'il fallait donc appeler l'enfer à son secours pour se composer des titres à l'intérêt, et trouver dans le pays des chimères, ce qu'on savait couramment en ne fouillant que l'histoire de l'homme dans cet âge de fer' (p. 53). While he admired The Monk, 'supérieur, sous tous les rapports, aux bizarres élans de la brillante imagination de Radcliffe' (p. 52), de Sade believed that the intensification of horror that Revolutionary terror necessitated had enfeebled the Gothic. Resorting to an excess of either the marvellous or mystification, Gothic novelists could only alienate their readers.

Unlike de Sade, Jane Austen had no direct experience of the French Revolution. She was, however, a close friend of her cousin (and later sister-in-law), Eliza, Comtesse de Feuillide, whose husband was guillotined in February 1794, at the height of the Terror. ${ }^{45}$ And her parody of the Gothic novel, Northanger Abbey, first published posthumously in 1818 but composed in 1798-99, ${ }^{46}$ shows the same awareness of the inextricable links between Gothic terror and the Terror seen in other writers of the Revolutionary decade. The locus classicus is the passage in which the heroine, Catherine Morland, is conversing with her suitor, Henry Tilney, and his sister Eleanor. After Henry has delivered a 'short disquisition on the state of the nation,' Catherine, 'in rather a solemn 
tone of voice, uttered these words, "I have heard that something very shocking indeed, will soon come out in London ... more horrible than any thing we have met with yet."',47 A devotee of the Gothic novel, currently immersed in Radcliffe's The Mysteries of Udolpho, Catherine is anticipating the latest 'shocking,' 'horrible' Gothic production. She does not know its 'author,' but has heard that it will be 'uncommonly dreadful. I shall expect murder and every thing of the kind' (p. 112). Her friend Eleanor, however, supposing that some 'dreadful riot' is expected in the streets of London, assures Catherine that 'proper measures will undoubtedly be taken by government to prevent its coming to effect.' Further complicating the passage is the nature of Henry's éclaircissement, which confuses as much as it clarifies. An ironic reading of his declaration to Catherine, 'my stupid sister has mistaken all your clearest expressions' (p. 113), would suggest that the opposite is true: that Catherine's talk of 'expected horrors in London' is obviously misleading, and cannot readily be understood to refer to Gothic horrors. But as many Austen critics have noted, such an ironic reading is unsatisfactory; the confusion between the two women is a sign of the times, and it is Henry's attempted resolution, rather than their misunderstanding, that seems fatuous.

Although a parody of the Gothic, Northanger Abbey is not designed to show that Gothic terrors are groundless. At the end of the novel, after all, Catherine resolves that her earlier fears of Henry's father, General Tilney, were justified, and that in suspecting him of 'either murdering or shutting up his wife, she had scarcely sinned against his character, or magnified his cruelty' (II, xv, p. 247). What had seemed to be Gothic imaginings are quite rational fears, and Henry's earlier assurances 'Remember the country and the age in which we live. Remember that we are English, that we are Christians' (II, ix, p. 197) - come to seem absurdly complacent. When Henry proceeds to state that, in England, 'every man is surrrounded by a neighbourhood of voluntary spies' ( $p$. 198), he is alluding, as Robert Hopkins has shown, to government agents employed by the Pitt ministry to repress radical and reform movements. ${ }^{48}$ In its commingling of Gothic and natural terrors, of the General's oppressive abbey and the oppressions of everyday life, Northanger Abbey is replying indirectly to the author of the 'Terrorist System of Novel-Writing,' the essay published in 1797, a year before Austen began to write her novel. The Gothic, she implies, is not a glorification but an acknowledgment of the dangers of the times.

By the end of the 1790s, discussions of the role of terror in literature had moved far beyond Dennis's amplification of Aristotle and Longinus. As Burke observed in Letters on a Regicide Peace (1796), all the horrors of even the most appalling Gothic novels pale before the actual 
events his own writings depict with a Gothicist's eye for the macabre: 'out of the tomb of the murdered monarchy in France has risen a vast, tremendous, unformed spectre, in a far more terrific guise than any which ever yet have overpowered the imagination, and subdued the fortitude of man. ${ }^{\prime 49}$ Even The Monk, published in the same year as Burke's final, apocalyptic work, could scarcely evoke Gothic terrors more horrid than these.

PETER SABOR

Queen's University

\section{Notes}

1 Montague Summers, The Gothic Quest: A History of the Gothic Novel (1938; London: Fortune Press, 1969), p. 21.

2 Devendra Varma, 'The Background: Origins and Cross-Currents,' in The Gothic Flame (1957; Metuchen, N.J.: Scarecrow Press, 1987), pp. 23-41.

3 Dan J. McNutt, The Eighteenth-Century Gothic Novel: An Annotated Bibliography of Criticism and Selected Texts (New York: Garland, 1975), pp. 31-47.

4 Frederick S. Frank, The First Gothics: A Critical Guide to the English Gothic Novel (New York: Garland, 1987), pp. xx-xxi.

5 Frank, 'The Gothic Romance,' in Horror Literature: A Core Collection and Reference Guide, ed. Marshall B. Tymn (New York: R.R. Bowker, 1981), p. 11.

6 See especially Alfred E. Longueil, "The Word "Gothic" in Eighteenth-Century Criticism,' Modern Language Notes, 38 (1923): 453-60. In this essay I am concerned only with literary Gothicism; its architectural, typographical, geographical and other connotations are not part of my subject.

7 Longueil, p. 454; John Dennis, The Advancement and Reformation of Modern Poetry,' The Critical Works of John Dennis, ed. Edward Niles Hooker (Baltimore: Johns Hopkins Press, 1939-43), I, 203; Joseph Addison, The Spectator 63 (12 May 1711), ed. Donald F. Bond (Oxford: Clarendon Press, 1965), I, 271. For further examples, see B. Sprague Allen, 'Classical Criticism of "Gothic Taste,"' Tides in English Taste (1619-1800): A Background for the Study of Literature (Cambridge, Mass.: Harvard University Press, 1937), II, 87-99.

8 Dennis, letter of 25 October 1688; Critical Works, II, 381.

9 Addison, Spectator 419 (1 July 1712), III, 571.

10 See Samuel Holt Monk, The Sublime: A Study of Critical Theories in XVIII-Century England (1935; rev. ed. Ann Arbor: University of Michigan Press, 1960), pp. 10, 67-68.

11 Monk, The Sublime; Walter John Hipple, Jr., The Beautiful, the Sublime, $\mathcal{E}$ the Picturesque in Eighteenth-Century British Aesthetic Theory (Carbondale: Southern Illinois University Press, 1957). 
12 James Boswell, Life of Johnson, ed. George Birkbeck Hill and L.F. Powell (Oxford: Clarendon Press, 1934-64), 16 October 1769, June 1784; II, 90, IV, 314.

13 Richard Hurd, Letters on Chivalry and Romance (1762), ed. Hoyt Trowbridge (Los Angeles: Augustan Reprint Society no. 101-102, 1963), p. 1.

14 Hurd, p. 49. The revisions are recorded in Edith J. Morley's edition of the Letters (London: Henry Frowde, 1911). As Trowbridge notes in his edition, however (p. ii), the revisions said by Morley to have been made by 1788 had in fact been made by 1765 .

15 Monthly Review, 27 (1762), 81. For the reception of Hurd's treatise, see Edward Niles Hooker, 'The Reviewers and the New Criticism 1754-1770,' Philological Quarterly, 13 (1934): 194-95.

16 Trowbridge, ed., p. iii; see also Trowbridge, 'Bishop Hurd: A Reinterpretation,' PMLA, 58 (1943), 450-65.

17 Henry Home, Lord Kames, Elements of Criticism (1762; 6th ed. London, 1785), II, xxi, pp. 364-66.

18 Samuel Richardson, letter of 15 December 1748; Selected Letters of Samuel Richardson, ed. John Carroll (Oxford: Clarendon Press, 1964), pp. 104-05.

19 Edmund Burke, Philosophical Enquiry, ed. James T. Boulton (1958; rpt. Notre Dame, Indiana: University of Notre Dame Press, 1968), IV, vii, p. 136.

20 Walpole, letter to William Mason, 3 March 1781; The Yale Edition of Horace Walpole's Correspondence, ed. W.S. Lewis, XXIX (New Haven: Yale University Press, 1955), 117. For Walpole's copy of Elements of Criticism, see Allen T. Hazen, A Catalogue of Horace Walpole's Library (New Haven: Yale University Press, 1969), II, 488.

21 Gray, letter to Walpole, 30 December 1764; Yale Edition, XIV, 137.

22 George James ('Gilly') Williams, letter to George Selwyn, 19 March 1765, Yale Edition, XXX, 177; Critical Review, XIX (1765), 469; John Langhorne, Monthly Review, XXXII (1765), 394. These items are collected in Horace Walpole: The Critical Heritage, ed. Peter Sabor (London: Routledge \& Kegan Paul, 1987), 66-72.

23 Walpole, The Castle of Otranto, ed. W.S. Lewis (Oxford: Oxford University Press, 1964), p. 4.

24 Warburton's note to Pope's Epistle to Augustus, 1. 146; Critical Heritage, p. 75. For a useful discussion of Warburton's comment, see Arthur L. Cooke, 'Some Side Lights on the Theory of the Gothic Romance,' Modern Language Quarterly, 12 (1951): 430-31.

25 Letter to Robert Jephson, 27 January 1780; Yale Edition, XLI, 409-10.

26 Reeve, The Old English Baron, ed. James Trainer (London: Oxford University Press, 1967), p. 4.

27 Walpole, letter to William Mason, 8 April 1778; Yale Edition, XXVIII, 381-82.

28 Critical Review, 2nd series XI (1794), 361; cited by Cooke, p. 434. The attribution of this review to Coleridge made by several critics is refuted by Charles I. Patterson, 'The Authenticity of Coleridge's Reviews of Gothic Romances,' JEGP, 50 (1951): 517-21.

29 The influence of The Castle of Otranto is often overstated by critics of the Gothic; see, for example, K.K. Mehrotra, Horace Walpole and the English Novel: A Study of the Influence of 'The Castle of Otranto' 1764-1820 (1934; New York: Russell and Russell, 1970). In her Mothers of the Novel: 100 Good Women Writers before Jane 
Austen (London: Pandora, 1986), Dale Spender does enthuse about Clara Reeve (pp. 230-32), but without paying any close attention to her novels.

30 See Samuel Kliger, "The "Goths" in England: An Introduction to the Gothic Vogue in Eighteenth-Century Aesthetic Discussion,' Modern Philology, 43 (1945): 107-17; Kliger, The Goths in England: A Study in Seventeenth and Eighteenth-Century Thought (Cambridge, Mass.: Harvard University Press, 1952); and Mark Madoff, 'The Useful Myth of Gothic Ancestry,' Studies in Eighteenth-Century Culture, 8 (1979): 337-50. Kliger's claims are challenged by Robert Donald Spector, English Literary Periodicals and the Climate of Opinion during the Seven Years' War (The Hague: Mouton, 1966), and by Michael Meehan, Liberty and Poetics in Eighteenth-Century England (London: Croom Helm, 1986), pp. 76-78.

31 William Whitehead in The World, no. 12, 22 March 1753, cited by Kliger, 'The "Goths,"' p. 116; reviews by Griffiths (1756) and Kenrick (1759), cited by Spector, p. 366.

32 Paulson, Representations of Revolution (1789-1820) (New Haven: Yale University Press [1983]), pp. 220-21.

33 Paulson, pp. 57-87.

34 Walpole, letter of 25 July 1789; Yale Edition, XLII, 251.

35 Walpole, letter of 18 August 1792; Yale Edition, XXXIV, 155.

36 Walpole, letter of 4 September 1794; Yale Edition, XXXIV, 204.

37 Reeve, Memoirs of Sir Roger de Clarendon (London, 1793), I, xvi.

38 Knight, The Landscape (1794; 2nd ed. London, 1795), III, $249-79$.

39 Knight, Analytical Inquiry (1805; 4th ed. London, 1808), III, i, 67, p. 384.

40 Knight, The Progress of Civil Society (London, 1796), VI, 505-08.

41 de Staël, 'Essai sur les fictions,' in Oeuvres complètes de Mme la Baronne de Staël (Paris, 1820), II, 178.

42 Mathias, The Pursuits of Literature (1794-97; 10th. ed. London, 1799), pp. 161-62. For a useful discussion of this and many other responses to The Monk, see André Parreaux, The Publication of 'The Monk': A Literary Event 1796-1798 (Paris: Didier, 1960).

43 'Terrorist System of Novel-Writing,' Monthly Magazine, 4 (1797), 102.

44 de Sade, Idée sur les romans (1800), ed. Jean Glastier (Bordeaux: Ducros, 1970), p. 48.

45 For a good account of Austen's friendship with de Feuillide and exposure to Revolutionary ideas, see Warren Roberts, Jane Austen and the French Revolution (London: Macmillan, 1979).

46 For the composition of Northanger Abbey, see A. Walton Litz, 'Chronology of Composition,' in The Jane Austen Handbook, ed. J. David Grey (London: Athlone Press, 1986), pp. 49-50.

47 Austen, Northanger Abbey, vol. V of The Novels of Jane Austen, ed. R.W. Chapman, 3rd ed. (London: Oxford University Press, 1969), I, xiv, pp. 111-12.

48 Hopkins, 'General Tilney and Affairs of State: The Political Gothic of Northanger Abbey,' Philological Quarterly, 57 (1978): 213-24.

49 Burke, Letters on a Regicide Peace (1796; cited in Paulson, p. 72). 